\title{
Web sites selling cigarettes: how many are there in the USA and what are their sales practices?
}

\author{
Kurt M Ribisl, Annice E Kim, Rebecca S Williams
}

\begin{abstract}
Objectives-To estimate the number and geographic location of web sites selling cigarettes in the USA, and to examine their sales and marketing practices.

Methods-Comprehensive searches were conducted using four keyword terms and five popular internet search engines, supplemented by sites identified in a news article. Over 1800 sites were examined to identify 88 internet cigarette vendors.

Measures-Trained raters examined the content of each site using a standardised coding instrument to assess geographic location, presence of warnings, products sold, and promotional strategies.

Setting-USA.
\end{abstract}

Results-Internet cigarette vendors were located in 23 states. Nearly half $(n=43)$ were located in New York state, and many were in tobacco producing states with low cigarette excise taxes. Indian reservations housed 49 of the 88 sites. Only $28.4 \%$ of sites featured the US Surgeon General's health warnings and $81.8 \%$ featured minimum age of sale warnings. Nearly all sites $(96.6 \%)$ sold premium or value brand cigarettes, $21.6 \%$ sold duty-free Marlboros, and $8.0 \%$ sold bidis. Approximately one third featured special promotional programmes.

Conclusions-Internet cigarette vendors present new regulatory and enforcement challenges for tobacco control advocates because of the difficulty in regulating internet content and because many vendors are on Indian reservations.

(Tobacco Control 2001;10:352-359)

Department of Health Behavior and Health Education, University of North Carolina School of Public Health, Chapel Hill, and the ${ }^{*}$ Lineberger Comprehensive Cancer Center, UNC School of Medicine, North Carolina, USA K M Ribisl A E Kim

R S Williams

Correspondence to: Kurt M Ribisl PhD, UNC School of Public Health, Department of Health Behavior and Health Education, Campus Box 7440, Chapel Hill, NC 27599, USA

kurt_ribisl@unc.edu

Received 22 March 2001 and in revised form

18 August 2001 . Accepted

19 September 2001
Keywords: youth access; internet; web sites; policy

Tobacco products are a major retail item in the USA. Over 47 million adults ${ }^{1}$ and 4 million teenagers smoke cigarettes. ${ }^{2}$ Annual sales of tobacco products exceed $\$ 40$ billion $^{3}$ and there are approximately 543000 tobacco retailers in the country. ${ }^{4}$ Smokers have traditionally purchased their cigarettes either by the pack or the carton from local retail outlets. These local retail outlets are now facing new competition from the growing number of e-commerce sites. Internet cigarette vendors (ICVs) include those that sell online exclusively, as well as local "brick and mortar" retail outlets that advertise and sell tobacco products on the internet. More Americans are online than ever, and many of them are purchasing products on the internet. As of August 2000, over 116.5 million
Americans were online and $42 \%$ of US households had a computer with internet access. ${ }^{5}$ Over $47 \%$ of American internet users have purchased something online, and consumers report that one of the primary attractions of online shopping is finding low prices. ${ }^{6}$

Increased state taxes on cigarettes have fuelled demand among smokers who seek refuge from escalating retail prices. In the USA, state excise taxes vary considerably. Vendors on Indian reservations sell tax-free cigarettes, and excise taxes are low in tobacco producing states such as Virginia $(\$ .025$ per pack of 20 cigarettes), Kentucky (\$.03), and North Carolina (\$.05). High excise taxes are featured in states such as California (\$.87), Alaska (\$1.00), Hawaii (\$1.00), and New York $(\$ 1.11) .{ }^{78}$ Given that each carton contains 10 packs, a smoker buying cigarettes in New York will pay over $\$ 10.00$ more per carton in excise taxes than a smoker in Virginia. In the past, when a state raised its excise tax on cigarettes, smokers who did not quit would either pay the increased price, or travel to Indian reservations or neighbouring states with cheaper prices. However, the internet offers the possibility of purchasing from Indian reservations or from states with lower excise taxes without having to physically drive there. A ready source of cheap cigarettes is now a mouse click away. This may have significant public health implications because tobacco consumption is adversely affected by price. When cigarette prices increase, smokers are likely to smoke less, change to cheaper generic brands, or quit smoking altogether. ${ }^{9-12}$ For instance, in California a 50 cent increase in state excise taxes (proposition 10) was followed by a $29 \%$ decrease in cigarette sales. ${ }^{13}{ }^{14}$ Although the majority of this decrease was probably caused by reduced consumption, media reports speculated that many California smokers were simply avoiding high taxes by buying directly from internet vendors. ${ }^{15-17}$

Much of the existing information on internet cigarette vendors has come from anecdotal media reports. For instance, newspaper reports have estimated that the overall number of web sites selling cigarettes ranges anywhere from $40,{ }^{14} 70,{ }^{18} 100,{ }^{19}$ and even up to "thousands." 20 A recent report commissioned by Brown and Williamson Tobacco Companies conducted by FIA International Research claimed there are 136 sites selling cigarettes. ${ }^{21}$ Several sources have suggested that ICVs are located mostly on Indian reservations or in tobacco producing states with low state excise taxes. ${ }^{18}{ }^{21-23}$ One report claims that at least three dozen sites are 
operated by the Seneca Indians in western New York, making it "the country's capital for tax-free cigarettes sold through the world wide web." 24

To the best of our knowledge, no published peer reviewed studies have examined web sites that sell cigarettes. The present study attempts to fill this void in the literature by using a rigorous internet based searching and sampling methodology to estimate the number of internet cigarette vendors. In addition, a standardised coding system is used to determine their characteristics including geographic location, presence of age and health warnings, and sales and marketing practices.

\section{Methods}

WEB SITE IDENTIFICATION PROCEDURES

There is currently no standardised method of sampling content featured on the world wide web. ${ }^{25} 26$ In the absence of standardised protocols, we employed a searching strategy similar to those utilised in studies of Ewings sarcoma ${ }^{27}$ and herbal remedy web sites. ${ }^{28}$ Both of these studies identified their study sample by entering multiple keywords into multiple search engines and by assessing either the first $100^{27}$ or $250^{28}$ hits from each search to determine web site eligibility for the study.

We used multiple keywords and search engines for several reasons: (1) approximately $85 \%$ of internet users rely on a search engine to locate information ${ }^{29}$; (2) industry studies show that users employ approximately three keywords in a given search session ${ }^{30}$; and (3) the best single search engine only covers about $16 \%$ of the web, but combining the results of multiple search engines raises coverage to nearly $42 \%$. $^{31}$

To identify the best keywords we began by first locating approximately a dozen ICVs and examining the words featured on each site's main page and metatags. Metatags provide keywords to help search engines find the site. Most browsers have a feature that allows users to view the underlying source code, including metatags. These approaches yielded a pool of 11 potential search keywords (cheap cigarettes, cheap smokes, cheap tobacco, discount cigarettes, discount smokes, discount tobacco, low price cigarette, inexpensive cigarette, mail order cigarette, online cigarette, and tax free cigarette). All 11 potential keywords were then typed into six major search engines used in an earlier study of search engine coverage ${ }^{31}$ to determine which keywords were most efficient in identifying ICVs. "Discount cigarette", "cheap cigarette", "mail order cigarette", and "tax free cigarette" were selected as the four best keywords because they were the most efficient in locating ICVs, and at least one of these four keywords appeared in nearly all of the metatags for sites that were found using the other seven potential keywords.

To identify the search engines, we relied on popularity rankings. Media Metrix (www.mediametrix.com) ratings for August 1999 (the most current ratings at the time of the data collection) were used to identify the top five most widely used internet search engines. The four keywords were entered into these search engines, except for Yahoo! (http:// www.yahoo.com), which is a category based internet search catalogue that required a slightly different strategy. Web sites on Yahoo! are organised hierarchically within categories. To identify the Yahoo! categories for cigarette vendors, two keywords-"smoking" and "cigarette"-were searched. The keyword "smoking" yielded 36 category matches and the keyword "cigarette" yielded five category matches. Of these 41 total category matches, only one unique category listed cigarette vendor sites: business and economy $>$ companies $>$ hobbies $>$ smoking. This searching strategy is depicted in fig 1 .

Internet cigarette vendors were identified through searches conducted during a two week period in November 1999 by two raters (AK and RW). To assess a manageable number of web sites, all Yahoo! category search results and the first 100 "hits" for all keywords on the other four search engines were analysed to determine whether or not they were potential cigarette vendors. The searches also yielded two "gateway" sites that listed links to other cigarette vendor sites. All of these links were pursued to determine whether the listed sites met study inclusion criteria. Two months following the initial search, a Business Week article on internet cigarette vending published the URL for another gateway site <http:// www.discount-cigarettes.org $>$ that listed links to 48 internet vendors. To be as comprehensive as possible, links on this gateway site were also included. A total of 1808 sites were examined to determine their eligibility for the study (fig 1).

INCLUSION CRITERIA

For the purpose of this study, a US internet cigarette vendor was defined as a web site that: (1) sells cigarettes; (2) allows the purchaser to order either online or via phone/fax/mail order; and (3) is based in the USA. Cigarettes were broadly defined to include name brand, generic brand, own brand, and clove cigarettes (Kreteks), as well as bidis. Sites that sell other tobacco products such as cigars and smokeless tobacco but do not sell cigarettes were excluded. Web sites of retail tobacco shops that only advertise cigarettes but do not offer a way to purchase them online or by phone, fax, mail order were excluded. Because we were primarily interested in vendors that must comply with US laws and regulations governing cigarette sales, only US based cigarette vendor sites were included in this study.

Similar to other studies of internet web sites, ${ }^{27}$ multiple raters determined the eligibility of the sites. To ensure consistency in coding, the inter-rater reliability was initially assessed on a sample of 100 sites. There was $97 \%$ agreement $(\kappa=0.91, p<0.001)$. Given this excellent level of agreement, one rater was used to determine the eligibility of the remaining 1708 sites.

Of the total 1808 sites examined, 455 met the inclusion criteria. The names and web site universal resource locator (URL) of these 455 
were then examined to rule out duplicates. For uncertain cases, contact information such as phone number and mailing address for both web sites was compared to determine if they were of the same origin. The site was contacted directly if more information was needed. After expunging duplicates, 88 unique ICV sites comprised the study sample (fig 1 ).

CODING PROCEDURES

Web researchers recommend keeping downloaded records of web sites because they are not permanent. ${ }^{25}$ The final sample of unique ICV web sites was downloaded and archived using WebRecord's Research Pro Version 2.0 in November 1999 and January 2000 (for the additional sites identified from the Business Week article). Four sites could not be archived using this software, so hard copies of all pages of these sites were printed and used for content analysis. A standardised coding form and codebook were developed and both raters were trained to use these instruments. Both raters independently coded all 88 web sites. Raters thoroughly explored all areas within the web site. Forms were sent to a commercial data entry firm and any discrepancies between raters were resolved through discussion with the first author (KR).

MEASURES

The content analysis rating form reflected four areas of assessment: (1) web site location and characteristics; (2) health and age warnings, (3) products sold and purchasing methods; and (4) promotional strategies.

Web site location and characteristics

Information collected included the city and state location, and whether it was on an Indian reservation. Web site characteristics included number of links present on the site and

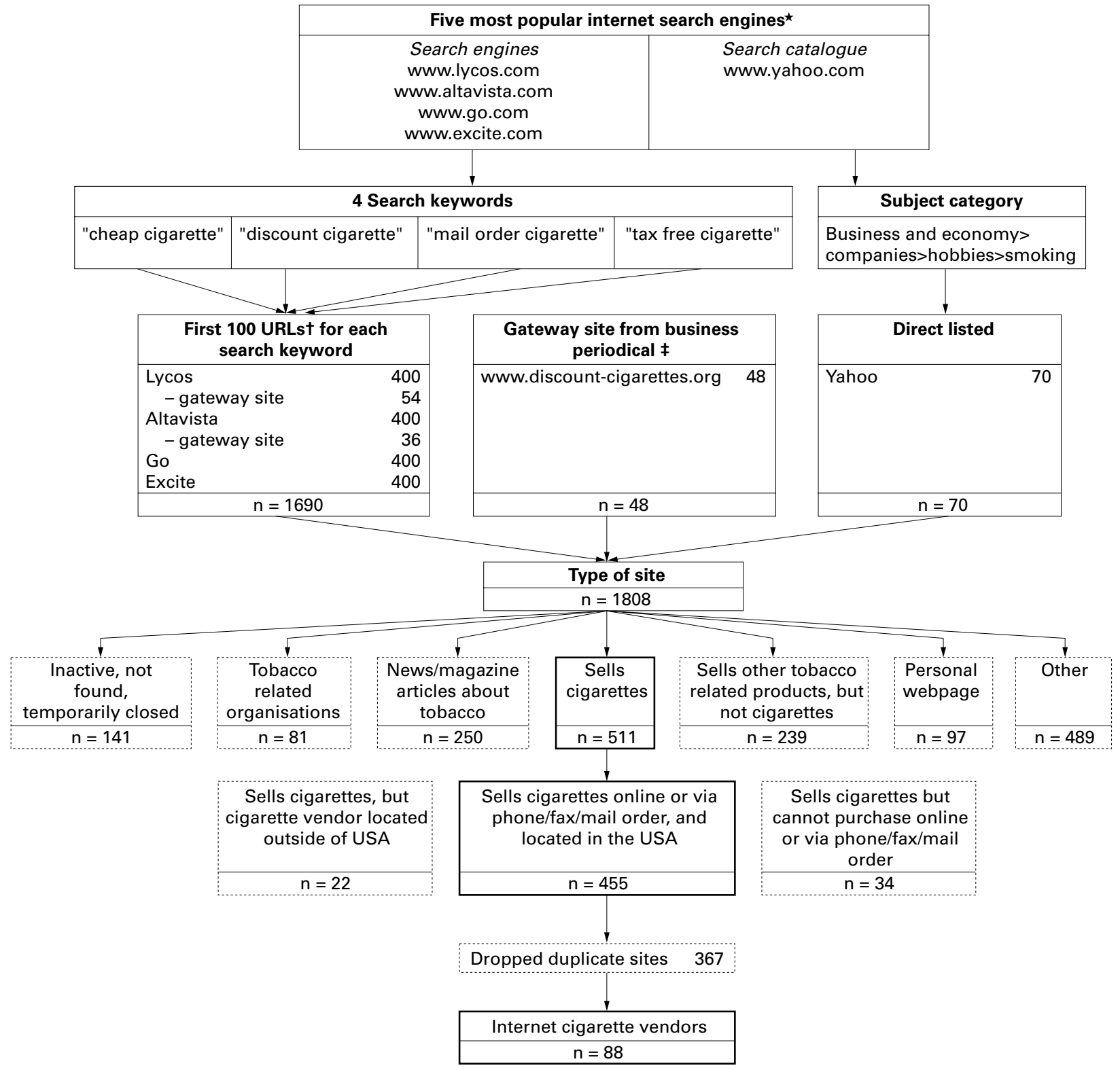

Figure 1 Web site identification procedures and inclusion criteria for study of internet cigarette vendors. *As ranked by www. mediametrix.com for August 1999. (Accessed November 1999. The top five search engine sites remained unchanged in a subsequent ranking for November 1999). + URL, universe resource locator. $\neq$ Business Week. Larry Armstrong “All the tar and none of the taxes." 13 December 1999, p 8. 


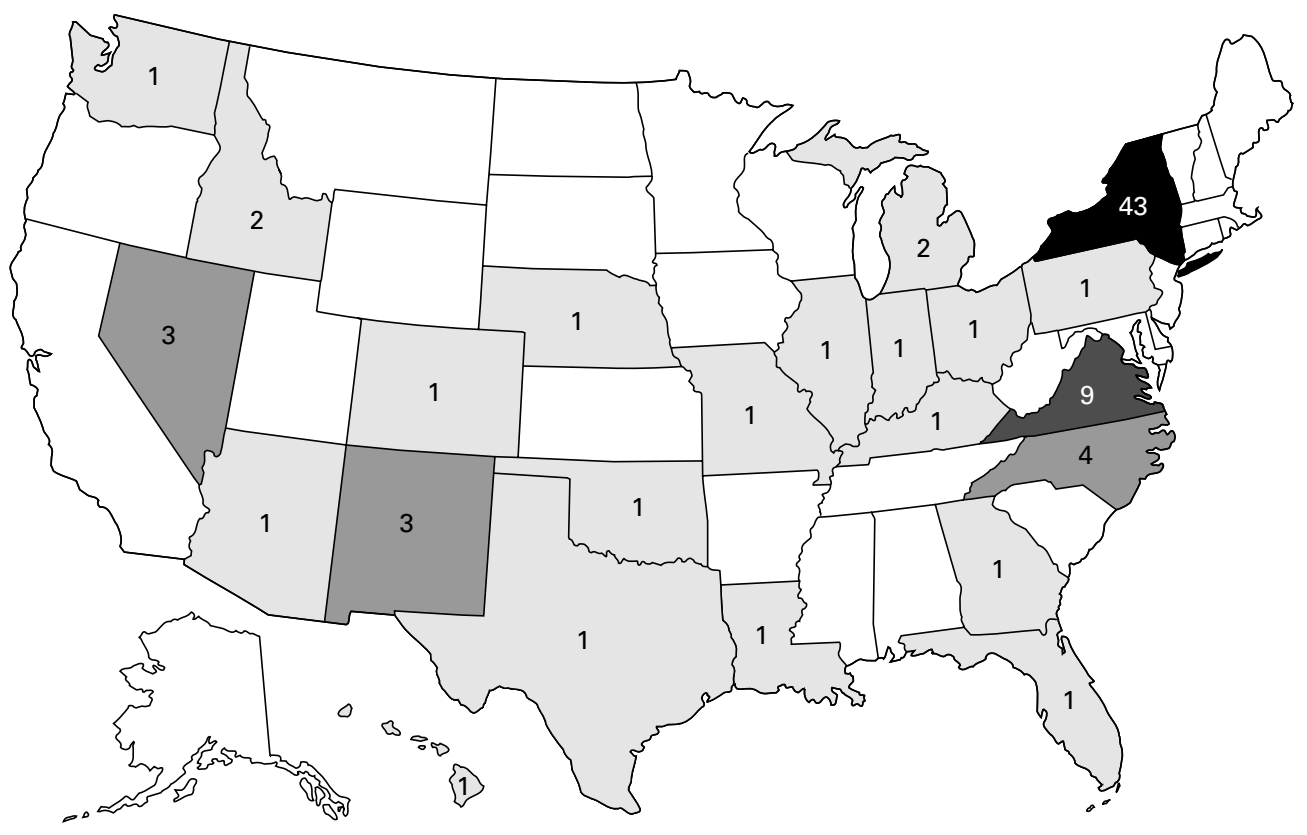

$\square 0 \square 1-2 \quad \square 3-4 \quad \square 5-10 \quad \square>10$

Figure 2 Number of internet cigarette vendors by state, USA, November 1999 to fanuary 2000 ( $n=88$ ). State location of six internet vendors could not be determined based on information from the website or personal inquiry.

whether the vendor was an actual retail store. Web sites were categorised as retail stores if information such as store hours, directions to store, or pictures of the actual store and/or store owners were posted.

Health and age warnings

The presence of one of the four rotating US Surgeon General's health warnings was coded. Sites with generic warnings such as "Health warning: if you do not smoke, please do not start now!" < http://www.cheap-tobacco.com> were not counted. Warnings about minimum age to purchase cigarettes were also assessed.

\section{Products sold and purchasing methods}

Raters collected information on the number of cigarette brands, the types of cigarette, tobacco, and non-tobacco products sold, whether cigarettes were sold by the pack or carton, and the minimum purchase necessary to process the order. Data on purchasing methods included accepted method of payment (for example, credit card, money order/certified check) and whether cigarettes could be ordered online, by mail, fax, or phone. The mode of delivery was also assessed.

\section{Promotional strategies}

Information was collected on special promotions and cigarette advertising, such as reduced price specials, free gifts with purchase, and weekly/monthly specials. Data were collected on whether the site mentioned the Jenkins Act, a US Federal law that regulates mail order sales of cigarettes. This was relevant because web sites ship their orders through mail. Advertising strategies, such as explicit promotion of tax-free cigarettes and posting of scanned cigarette package images were also assessed.

ANALYSIS

Descriptive statistics were computed using SPSS Statistical Software, version $10 .^{32}$ Confidence intervals were not calculated because this study attempted to identify a population of internet cigarette vendors and did not sample from a known population of ICVs.

\section{Results}

WEB SITE LOCATION AND CHARACTERISTICS A total of 88 unique US based ICVs were downloaded and analysed. Vendors were located in 23 states (fig 2), with most in New York $(n=43)$ (fig 3$)$, Virginia $(n=9)$, and North Carolina $(n=4)$. Over half of the ICVs were located on Indian reservations $(n=49)$, and $80 \%$ of the ICVs on Indian reservations were based in New York state. Of the 43 ICVs located in New York, $90.6 \%$ of them were on Indian reservations.

Thirty one per cent of ICVs $(n=27)$ were retail shops that had taken their business online. These retail shops varied from a local "mom and pop" store such as Tony's Food Mart (www.tonysfoodmart.com) in North Carolina to Big Bear Discounts (www.bigbd.com), a Seneca owned business located on the Cattaraugus Indian Reservation in Western New York (table 1).

Thirty six ICVs had links to other sites, with wide variation in the number of external links. Five sites linked to pro-smoking or smoker's rights organisations, 10 sites had links to other tobacco related chatrooms or web pages, and 


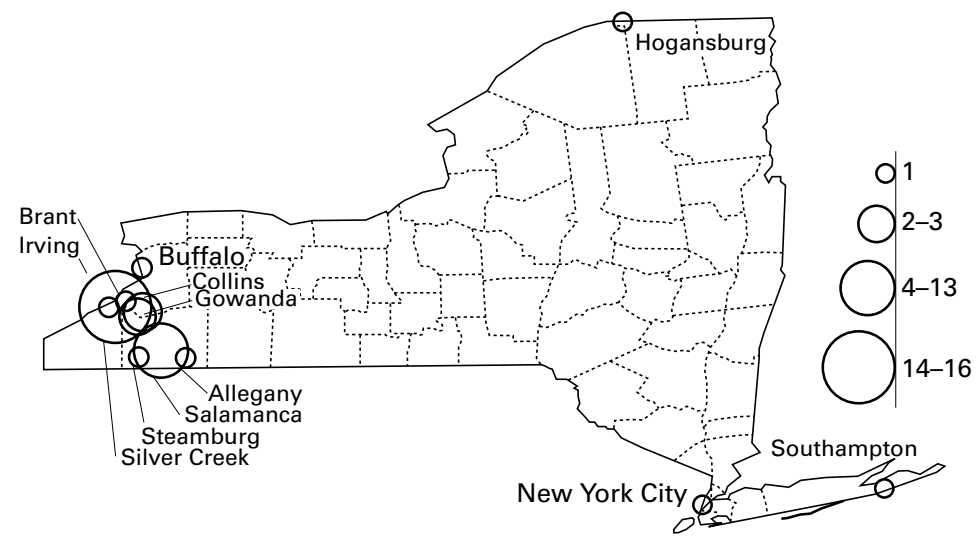

Figure 3 Number and geographical distribution of internet cigarette vendors in New York state, November 1999 to Fanuary $2000(n=43)$.

several had links to tobacco vendors $(n=3)$ or tobacco companies $(n=3)$.

HEALTH AND AGE WARNINGS

Only $28.4 \%$ of the ICVs featured a US Surgeon General's warning $(n=25)$, whereas the majority $(81.8 \%)$ featured a warning about the minimum age of sale for tobacco products (table 2).

PURCHASING METHOD

Internet cigarette vendors offered various methods to purchase and receive delivery of cigarettes. A buyer could order directly online $(\mathrm{n}=75)$, or by phone $(\mathrm{n}=72)$, fax $(\mathrm{n}=58)$,

Table 1 Presence of retail outlet and external links for internet cigarette vendor web sites $(n=88)$

\begin{tabular}{ll}
\hline & Number (\%) \\
\hline $\begin{array}{l}\text { Vendor on Indian reservation } \\
\text { Vendor operates a retail store }\end{array}$ & $49(55.7)$ \\
$\begin{array}{l}\text { Number of external link(s) } \\
\text { None }\end{array}$ & $27(30.7)$ \\
$1-2$ & $52(59.1)$ \\
$3-9$ & $13(14.8)$ \\
$10-49$ & $12(13.6)$ \\
$50-100$ & $9(10.0)$ \\
Type of link & $2(2.2)$ \\
Pro-smoking or smokers' rights & $5(5.7)$ \\
organisation & $3(3.4)$ \\
Tobacco companies & $3(3.4)$ \\
Tobacco vendor web site & $10(11.4)$ \\
$\begin{array}{l}\text { Other tobacco related sites, e.g. } \\
\text { chatrooms, personal web pages }\end{array}$ & \\
\hline * &
\end{tabular}

Table 2 Presence of health warnings, age verification procedures, and purchasing methods for internet cigarette vendors $(n=88)$

\begin{tabular}{ll}
\hline & Number (\%) \\
\hline Surgeon General's warning(s) & $25(28.4)$ \\
Presence of age warning(s) & $72(81.8)$ \\
Method of purchase & $75(85.2)$ \\
Submit online/ via email & $72(81.8)$ \\
Phone & $58(65.9)$ \\
Fax & $68(77.3)$ \\
Mail & \\
Method of payment & $80(90.9)$ \\
Credit card & $60(68.2)$ \\
Money order/certified check & $51(58.0)$ \\
Personal check & $2(2.3)$ \\
ATM card & $9(10.2)$ \\
Other & $33(37.5)$ \\
Delivery options & $46(52.3)$ \\
US postal service & $35(39.8)$ \\
UPS & \\
Not specified &
\end{tabular}

ATM, automated teller machine; UPS, United Parcels Service. or mail $(n=68)$. Credit cards were the most commonly mentioned method of payment, accepted by $90.9 \%$ of ICVs. Many ICVs also allowed alternative methods of payment including money order and/or certified checks $(n=60)$, personal checks $(n=51)$, and ATM (automatic teller machine) cards $(n=2)$. The most common mode of delivery offered was UPS courier service $(n=46)$, followed by US postal service $(n=33)$ (table 2$)$.

TYPES OF PRODUCTS

ICVs sold a wide range of cigarette products including premium, discount, and value brand cigarettes (97\%), clove cigarettes $(18 \%)$, and bidis $(8 \%)$. Eight ICVs sold their own cigarette brands, such as Cherokee cigarettes at <http:// www.cdbn.com>. Nineteen ICVs also sold duty-free Marlboros, grey market cigarettes manufactured for export that are now banned under the Master Settlement Agreement. Half of ICVs sold 50 or more different cigarette brands on their web sites. Some sites such as $<$ http://www.4discountcigarettes.com> advertised selling over 300 cigarette brands. Four sites allowed one pack as the minimum order, and almost a third of the sites required a minimum purchase of four or five cartons to process the order.

In addition to selling cigarettes, ICVs also sold other tobacco products such as cigars $(n=37)$ and loose tobacco $(n=23)$ (table 3). Two sites even sold tobacco seeds with instructional guides on how to grow tobacco at home. Another advertised a home tobacco kit that included a "handy guide that helps you understand how to plant, raise, harvest, cure and

Table 3 Products sold and promotional strategies used by internet cigarette vendor web sites $(n=88)$

\begin{tabular}{|c|c|}
\hline & Number (\%) \\
\hline \multicolumn{2}{|l|}{ Types of tobacco products sold } \\
\hline \multicolumn{2}{|l|}{ Cigarettes } \\
\hline Premium/discount/value brand & $85(96.6)$ \\
\hline Clove & $16(18.2)$ \\
\hline Bidis & $7(8.0)$ \\
\hline Own brand & $8(9.1)$ \\
\hline Cigars & $37(42.0)$ \\
\hline Smokeless tobacco & $34(38.6)$ \\
\hline Loose tobacco & $23(26.1)$ \\
\hline Tobacco seeds & $2(2.3)$ \\
\hline Tobacco paraphernalia & $20(22.7)$ \\
\hline Other tobacco products & $8(9.1)$ \\
\hline Duty-free Marlboros sold & $19(21.6)$ \\
\hline \multicolumn{2}{|l|}{ Number of cigarette brands sold } \\
\hline 1 & $6(6.8)$ \\
\hline $2-4$ & $2(2.3)$ \\
\hline $5-10$ & $3(3.4)$ \\
\hline $11-49$ & $30(34.1)$ \\
\hline $50+$ & $44(50.0)$ \\
\hline \multicolumn{2}{|l|}{ Minimum purchase allowed ${ }^{\star}$} \\
\hline 1 packt & $4(4.6)$ \\
\hline 1 carton & $35(42.2)$ \\
\hline 2 cartons & $5(5.7)$ \\
\hline 3 cartons & $13(14.9)$ \\
\hline 4 cartons & $9(10.3)$ \\
\hline 5 cartons & $21(24.1)$ \\
\hline Non-tobacco products sold & $15(17.0)$ \\
\hline Mentions Jenkins Act & $4(4.5)$ \\
\hline \multicolumn{2}{|l|}{ Promotional strategies } \\
\hline Reduced prices & $20(22.7)$ \\
\hline Offers standing orders & $16(18.2)$ \\
\hline Weekly/monthly specials & $12(13.6)$ \\
\hline Gift with purchase & $3(3.4)$ \\
\hline Scanned images of cigarette packs or cartons & $36(40.9)$ \\
\hline Promotion of tax-free cigarettes & $29(33.0)$ \\
\hline Ads for specific tobacco brands & $7(8.0)$ \\
\hline
\end{tabular}

Data available for 87 sites.

†These four sites only sold packs within their home state. 
process your own tobacco products [to] make your own cigarettes for as low as $\$ 3.50$ a carton" <http://www.discount cigarettes.com $>$. Twenty ICVs sold tobacco paraphernalia such as cigar cutters, humidors, and lighters. Fifteen of the sites also sold non-tobacco products that ranged from teas and vitamins to Native American moccasins. In addition to selling cigarettes, Senecasmokes $<$ http://www.senecasmokes.com> sold "Herbal Viagra," which they touted as "the new all natural alternative to Viagra for men and women."

PROMOTIONAL STRATEGIES

Many of the ICVs offered a variety of special promotions. Twenty sites offered reduced prices while 16 allowed buyers to create standing orders to receive regular shipments of cigarettes. Twelve sites offered weekly/monthly specials and three offered gifts with purchase. Although 29 sites promoted selling "tax-free cigarettes," only four mentioned the Jenkins Act. Other advertising strategies employed by ICVs included scanned images of cigarette packs or cartons $(n=36)$ and advertisements for specific tobacco brands $(n=7)$.

\section{Discussion}

The goal of this study was to estimate the number of internet cigarette vendors in the USA, and to examine their sales and marketing practices. A comprehensive internet searching strategy was conducted during November 1999 and January 2000. A total of 88 unique internet cigarette vendors in the USA were identified, 43 of which were located in New York state. There were about as many internet vendors in New York state as the rest of the other 49 states combined. A total of 15 sites were located in three tobacco growing states, Virginia, North Carolina, and Kentucky, which have the lowest excise taxes on cigarettes in the country. Surprisingly, this study did not identify any internet cigarette vendors in California, a state with high rates of internet access $^{33}$ and over 35000 retail tobacco outlets. Nationally, there are approximately 534000 retail outlets selling tobacco products ${ }^{4}$ and this study identified only 88 internet cigarette vendors. Although over $44 \%$ of US businesses sell goods or services over the internet, ${ }^{6}$ it appears that fewer than $1 \%$ of retail outlets sold online at the time of this study. Moreover, the majority of internet vendors sold exclusively through the internet.

TAX REVENUE AND SOVEREIGNTY ISSUES ON THE INTERNET

Many states fear that the growth of internet sales will lead to decreased cigarette excise tax revenues. One survey of state tax administrators found that over half believed that internet sales of tobacco have created tax evasion problems in their jurisdiction. ${ }^{21}$ Forrester Research estimated that in $2005,14 \%$ of tobacco sales will occur online and that states will lose an estimated $\$ 1.4$ billion in tax revenue. ${ }^{34}$ This can have a major impact on states such as New York, which planned on raising $\$ 400$ million dollars annually for a new medical insurance programme for the working poor by raising its cigarette excise tax.

At the federal level, the US Congress has imposed a moratorium on the imposition of internet taxes. ${ }^{6}$ However, there is a federal provision dating from 1949 called the Jenkins Act, which was designed to prevent black market tobacco sales across state lines. The Jenkins Act requires vendors selling cigarettes to persons in other states to submit monthly reports to state tax administrators listing the identity of all individuals buying cigarettes and the amount they purchased. ${ }^{19}{ }^{23}$ Although this law has rarely been enforced, several states such as Alaska, California, Iowa, Washington, and Wisconsin are now starting to enforce it. ${ }^{35}$ The California Department of Equalization has sent out over 3200 letters to state residents who bought cigarettes from out-of-state companies and has collected over $\$ 416000$ in back taxes..$^{23}{ }^{35}$ Our study found that only four web sites informed potential buyers regarding the provisions of the Jenkins Act. In practice, several web sites ignore the law by failing to provide the names and purchasing habits of their customers to tax authorities, while others claim they are sovereign nations that are not subject to this law. ${ }^{36}$

One of the thorniest regulatory issues will be how to handle sales from Indian reservations. There are currently 558 federally recognised tribes in the USA. In New York, members of the Seneca Nation, for instance, claim that their 1842 treaty with the USA was a declaration of their sovereignty and freedom from external controls. In addition, they claim that New York civil laws do not apply to them because reservations are considered "interstate" by federal law. ${ }^{19}$ In contrast, the New York attorney general's office stated that it did not claim jurisdiction over transactions that occur on the reservation, but it did claim jurisdiction when deliveries were made from the reservation to other locations. The US Supreme Court has ruled that tax-free sales provisions apply only to Indians selling to other Indians. ${ }^{24}$ The large number of ICVs on Indian reservations in New York state came from vendors in the Seneca Nation. A recent newspaper article highlighted a native Seneca Indian who sold cigarettes by mail order for 14 years and who has been helping over a dozen Senecas establish their own web sites to sell cigarettes. ${ }^{24}$ This may partially explain why New York has more internet vendors than other states with large Indian populations such as New Mexico and Arizona.

\section{REGULATIONS AFFECTING INTERNET CIGARETTE} VENDORS

New York state enacted legislation effective January 2001 intended to limit mail order, telephone, and internet cigarette sales by prohibiting common carriers from delivering tobacco products to anyone other than a licensed or registered agent or dealer. ${ }^{37}$ This legislation stated that web site and mail order vendors who ship cigarettes must plainly and visibly mark the wrapper or container with the words 
"Cigarettes". Also, common or contract carriers, such as UPS or Federal Express, are restricted from knowingly transporting cigarettes to individual consumers. This legislation triggered lawsuits from both Brown and Williamson and Santa Fe Natural Tobacco companies who argued that this was an "unconstitutional interference with interstate commerce."19 A temporary restraining order initially blocked the implementation of the New York law, ${ }^{37}$ and ultimately, a federal judge overturned the law on constitutional grounds. ${ }^{39}$

The state of Rhode Island passed a less restrictive law that banned internet and mail order sales of cigarettes without age verification at delivery. ${ }^{40}$ The law stipulates that web retailers and mail order companies cannot instruct couriers to leave packages, that delivery people are not held responsible, and that there is up to a $\$ 1000$ fine for selling to minors. ${ }^{42}$ The Rhode Island law has not yet been challenged legally, and is actually supported by Brown and Williamson. ${ }^{41}$

Mandating age verification at delivery presents some difficulties for couriers. UPS currently has provisions to allow age verification, but Federal Express and the US postal service do not.

The present study found about one fourth of sites featured official health warnings, which is somewhat higher than a recent study of internet cigar vendors that found only $3.5 \%$ of sites featured health warnings. ${ }^{43}$ Under legislation introduced by US Congressman Meehan on 4 October 1999 entitled the "Internet Cigarette Warning Label Act" (H.R. 3007), internet vendors would be required to abide by the Federal Cigarette Labeling and Advertising Act that has required Surgeon General's warnings to appear on cigarette packaging and print advertising. It would also authorise the Federal Trade Commission to establish conspicuous warning labels for web sites. This legislation never made it beyond committee and expired in the 106th session of the US Congress.

STUDY LIMITATIONS

There are several limitations of the present study. Firstly, this study examined the written content featured on internet cigarette vendor web sites, but did not determine the actual practices of vendors. A second limitation was that our searching strategy might have missed some sites. Although we used a rigorous searching strategy using multiple keywords and search engines, even the best search engines do not cover the entire internet. ${ }^{31}$ Only about one third of sites feature metatag keywords, and search engines are more likely to select sites that are "popular" or linked to other sites. ${ }^{31}$ Therefore, our estimate of 88 internet cigarette vendors for early 2000 should be considered a lower bound estimate for the time frame of our search. Finally, one cannot be certain that the web sites identified by this study are representative of other ICVs not identified.

\section{What this paper adds}

A prior study found that there are a substantial number of web sites selling cigars, but there are no published empirical studies examining the sales practices of web sites selling cigarettes. As states increase their cigarette excise taxes, there is speculation that the internet will serve as an unregulated and ready source of tax-free or low tax cigarettes.

This study used a rigorous internet searching strategy to identify 88 web sites selling cigarettes in the USA. Most sites sold cigarettes only through the internet and not from a retail outlet. Some sites sold duty-free cigarettes, which are now banned under the Master Settlement Agreement. Sites also advertised that they sold cigarettes tax-free. Over half of the web sites were located on Indian reservations, which creates additional complications for regulating their sales practices because they are considered sovereign territory.

\section{FUTURE RESEARCH}

Longitudinal studies are needed to monitor the growth in the number of internet cigarette vendors and to examine changes in their marketing and sales practices. The Center for Media Education's 1998 follow up report ${ }^{44}$ found that most of the 38 internet cigarette vendors identified in their 1997 report $^{45}$ were out of business, suggesting that internet vendors may be quite transitory. Nevertheless, as e-commerce grows, the number of internet vendors is likely to grow even if individual vendors fail. Although most vendors identified in this study had a web only presence, even if 5\% of the 534000 US retail outlets sold cigarettes online, this would be a tremendous increase in the number of internet vendors. Another trend deserving examination is to monitor the major tobacco companies as they are now entering into mail order and internet sales of tobacco products. For instance, RJ Reynolds sells its smokeless cigarette Eclipse through its web site, $^{23}$ and Brown and Williamson recently announced plans to sell certain brands through mail order and eventually online. ${ }^{46}$

Epidemiologic studies are also needed. Studies should examine: what percentage of youth and adult smokers buy cigarettes on the internet, whether this is a supplement to retail purchasing or a sole source, and the primary reasons for buying online. Answering these questions will help identify what percentage of overall cigarette sales occur online and should help policy makers and state governments evaluate the amount of cigarette excise tax revenues that are not being collected.

\section{CONCLUSIONS}

This is perhaps the first study of its kind to estimate the number of internet cigarette vendors and their sales practices. The emergence of internet cigarette vendors presents many challenges for tobacco control advocates. State and federal legislation and 
enforcement will probably be needed to ensure that appropriate excise taxes are paid on cigarettes, that grey market cigarettes are not sold online, and that youth access to tobacco products is restricted. The findings from this study will be helpful in developing public health approaches to addressing the unique problems posed by internet cigarette vendors.

1 Centers for Disease Control and Prevention. Cigarette smoking among adults-United States, 1997. MMWR Morb Mortal Wkly Rep 1999;48:994-9.

2 Centers for Disease Control and Prevention. Tobacco use among high school students-United States, 1997. MMWR Morb Mortal Wkly Rep 1998;47:229-33.

3 US Department of Health and Human Services. Preventing tobacco use among young people. A report of the Surgeon General, 1994. Atlanta, Georgia: Public Health Service, Centers for Disease Control and Prevention, Office on Smoking and Health, 1994. (US Government Printing Office Publiand Health, 1994. (US Government

4 DiFranza JR, Peck RM, Radecki TE, et al. What is the potential cost-effectiveness of enforcing a prohibition on potential cost-effectiveness of enforcing a prohibition on

5 United States Department of Commerce and the National Telecommunications and Information Administration. Falling through the net: toward digital inclusion - a report on American's access to technology tools. Washington DC, 2000

6 United States Internet Council \& ITTA Inc. State of the Internet 2000. Washington DC; 1 September 2000.

7 Associated Press. NY jumps to No 1 cigarette tax. Albany, New York, 1 March, 2000.

8 Fishman JA, Allison H, Knowles SB, et al. State laws on tobacco control-United States, 1998. MMWR Morb Mortal Wkly Rep 1999;48(SS03):21-62.

9 Centers for Disease Control and Prevention. Cigarette smoking before and after an excise tax increase and an antismoking campaign-Massachusetts, 1990-1996. MMWR Morb Mortal Wkly Rep 1996;45:966-70.

$10 \mathrm{Hu}$ TW, Sung HY, Keeler TE. Reducing cigarette consumption in California: tobacco taxes vs an anticonsumption in California: tobacco taxes vs an anti-
smoking media campaign. Am $\mathcal{F}$ Public Health 1995; smoking media

11 Lewit EM, Hyland A, Kerrebrock N, et al. Price, public policy, and smoking in young people. Tobacco Control 1997;6(suppl 2):S17-24

12 Wasserman J, Manning WG, Newhouse JP, et al. The effects of excise taxes and regulations on cigarette smoking. $\mathcal{F}$ Health Econ 1991;10:43-64.

13 Demer L. Cigarettes sales down, revenue up. Anchorage Daily News. Anchorage, Alaska; 14 September 1999.

14 Warren J. Cigarette sales off $29 \%$ in state since 50 -cent tax hike. Los Angeles Times. Los Angeles, California; 1999:A3.

15 Howe K. Price rise puts heat on smokers: Run on cigarette sales and Internet vendors. San Francisco Chronicle. San Francisco, Californa; 1998:A1, A10-11.

16 O'Connell V. Cigarette price boosts send smokers scurrying for cheaper brands, outlets. Wall Street fournal. New York, NY; 1998:A4.

17 Staff. Drag net: cigarette buyers may go online to avoid new taxes. San fose Mercury News. San Jose, California; 1998:1 A, 18A

18 Scripps Howard News Service. E-cigarettes: discount sales of tobacco on web threaten US efforts to reduce smoking. Winston-Salem Journal. Winston-Salem, North Carolina; 2000 .
19 Delio M. E-tailers fuming over NY law. Wired.com; 2000 20 Koury C. Internet tobacco dealers targeted in AG's sting. Telegram \& Gazette; 2000

21 FIA International Research. Cigarette smuggling and the internet. New York; August 2000

22 Armstrong L. All of the tar and none of the taxes. Business Week; 1999.

23 Said C. Online sale of tobacco drawing a fight; critics say tax, age laws must apply to web market. San Francisco Chronicle. San Francisco, California; 2000.

24 Beebe M. Tobacco's new road. The Buffalo News. Buffalo, New York; 1999.

25 Mitra A, Cohen E. Analyzing the web: directions and challenges. In: Jones S, ed. Doing internet research: critical issues and methods for examining the net. Thousand Oaks, California: Sage, 1999:299.

26 Riffe D, Lacy S, Fico FG, eds. Analyzing media messages. Mahwah, New Jersey: Lawrence Earlbaum, 1998.

27 Biermann JS, Golladay GJ, Greenfield ML, et al. Evaluation of cancer information on the Internet. Cancer 1999; 86:381-90.

28 Veronin MA, Gilbert R. The validity of health claims on the world wide web: a systematic survey of the herbal remedy Opuntia. AfHP 2000;15:21-8.

29 Graphic Visualization and Usability Center. GVU's 10th WWW User Survey: URL: http://www.gvu.gatech.edu/ user_surveys/survey-1998-10/; October 1998.

30 Spink A, Bateman J, Jansen BJ. Searching the web: a survey of EXCITE users. Internet research: electronic networking of EXCITE users. Internet research:
applications and policy 1999;9:117-28.

31 Lawrence S, Giles CL. Accessibility of information on the web. Nature 1999;400:107-9.

32 Norusis J. SPSS for Windows, Release 10.0. Chicago, Illinois; 1999.

33 US Department of Commerce. Falling through the net: toward digital inclusion. Washington DC: USDC, 2000.

34 Rubin R, Charron C, Dorsey M. Online tobacco sales grow, states lose. Cambridge, Massachusetts: Forrester Research, 27 April 2001.

35 Wolverton T, Sandoval G. Taxes threaten booming sales of cigarettes online. CNET News.com; 2000.

36 Streitfeld D. Online tobacco sales ignite fight over taxes. Washington Post. Washington DC; 2000:A01.

7 Fairclough G. New York banning cigarette sales by mail, Web blocked by judge's ruling. The Wall Street fournal Interactive Edition. New York, 2000.

38 Fairclough G. BAT unit sues to block New York law banning sale of cigarettes on the web. The Wall Street fournal Interactive Edition. New York, 2000.

39 Fairclough G. Judge throws out a state law banning Internet, mail-order sales of cigarettes. The Wall Street fournal Interactive Edition. New York, 11 June 2001.

40 Lehourites C. RI restricts Internet tobacco sales. Associated Press; 2000.

41 Scherer R. States crack down on web tobacco sales. The Christian Science Monitor. New York, NY; 2000.

42 Corkery M. Law bans web sale of tobacco to minors. Providence fournal-Bulletin. Providence, Rhode Island; 2000.

43 Malone RE, Bero LA. Cigars, youth, and the Internet link. Am f Public Health 2000;90:790-2.

44 Center for Media Education. Tobacco targeted at youth on the internet: an update. Washington DC: Center for Media Education, December 1998.

45 Center for Media Education. Alcohol and tobacco on the web: new threats to youth. Washington DC: Center for Media Education; March,1997.

46 Fairclough G. BAT division will start taking phone, fax orders for cigarettes. The Wall Street fournal Interactive Edition. New York, 2000. 